\title{
Impact of Bio Safe Compounds and Resistance Inducers on Certain Soil Borne Diseases, Growth and Yield of Pea Plants (Pisum sativum L.)
}

Naglaa A. Taha, Y. A. Bayoumi* and Eman S. Hagag

Plant Pathology Research Institute, Agriculture Research Center, Sakha and *Horticulture Department, Faculty of Agriculture, Kafrelsheikh University, 33516Kafr El-Sheikh, Egypt

$\mathbf{T}$ The present work was carried out to study the effect of some saftey compounds, i.e. plant guard (Trichoderma harzianum), humic acid and compost tea and resistance inducers (salicylic acid and benzothiadiazole) besides fungicide (Vitavax-T)) on controlling soil borne diseases such as root rot and wilt of pea plants (cv. Master-B). Data comprised growth, yield and quality parameters under greenhouse and open field conditions during 2012 and 2013 growing seasons. All safe compounds and inducers were evaluated to control Fusarium solani, Fusarium moniliform, Fusarium oxysporum and Macrophomina phaseolina, the causal agents of pea root rot and wilt diseases compared to fungicide. Most treatments significantly protected pea plants from pre and post-emergence damping off, increased pea growth and yield components compared to control plants. Under open field conditions, pea plants were infected naturally with $F$. oxysporum f.sp. pisi, wilt \% was significantly reduced by all treatments compared to untreated plants (control). As a result of treatments, vegetative growth parameters (plant height, No. of leaves /plant, plant fresh and dry weight), chlorophyll content, yield parameters (green pod yield, total dry seed yield, pod length and weight of 100 seeds) and catalase antioxidant enzyme of pea plants were increased significantly compared to untreated plants. These results provide alternative and safe compounds to control pea wilt diseases and consequently, save the fungicide cost, reduce environmental pollution as well as improving plant growth and total yield of pea plants.

Keywords: Root Rot, Wilt, Pea, Growth, Yield, Trichoderma, Safe Compounds, Inducers.

\section{Introduction}

Peas (Pisum sativum L.) is one of the most important leguminous vegetables, cultivated during winter season in Egypt for local consumption and exportation. Green peas has a high rate in protein, amino acids and carbohydrates, so it is considered an important source for human food nutrition. In Egypt, peas cultivated area is 18478 ha with an average of 9.97 ton/ha of green peas and 2 ton/ ha of dry peas (FAOSTAT, 2014). Wilting is considered one of the high challenges facing peas cultivation, thus it is necessary to control diseases and enhance plant growth and yield by using safe compounds such as biological control agents and resistance inducers. Although, chemical control is the best for wilt disease but, it has high cost and harmful effect on human health and environment (Hafez et al., 2014). Accordingly, using safe compounds to control wilt diseases and improve plant growth and yield is of a paramount important. The use of biocontrol agents, humic substances, compost teas, salicylic acid, ...etc would build a reduction in the use of both fungicides and mineral fertilizers. Several investigators stated that usage of biological control treatments against pathogens proved to be successful and efficient in controlling many diseases and increasing growth, yield and quality of many vegetable crops (Callan et al., 1997 and Bayoumi \& Hafez, 2006). Likely, treating seeds or foliage treatment of many crops with biocontrol agents such Trichoderma spp. was effective to suppress many pathogens (Abdel-Kader et al., 2012), protect pea and radish

Correspondence: (ybayoumi2002@yahoo.com.sg)

DOI: $10.21608 /$ jsas.2017.1587.1019

C2017 National Information and Documentation Centre (NIDOC) 
seedlings against pathogens attack as well as reducing the incidence of damping-off (Lifshitz et al., 1986). However, Ghanbarzadeh et al. (2016) concluded that applying Trichoderma harzianum was less effective for wilt control than the chemical fungicides, but it highly improved growth and yield of onion plants.

Humic acids (HA) as a natural product leave a huge content of organic matter in soil and able to interact with mineral and organic compounds. They enhanced roots, leaves and shoots growth of many plants as well as stimulate nutrients uptake for major nutrients (Mohajerani et al., 2016). Similarly, Shehata et al. (2016) and Yasir et al. (2016) showed that HA increased fresh and dry weights of leaves, number of leaves, total yield and improved quality as well as chlorophyll and carotenoid contents of head lettuce and cucumber. Compost tea is applied commercially as a natural fertilizer activator for growth and yield of cucumber and other vegetables as well as to suppress several of diseases as substitutive control (Bayoumi and El-Kot, 2010, Martin and Brathwaite, 2012 and Kim et al., 2015).

Salicylic acid (SA) as resistant inducer plays an essential role in the defence response to pathogen attack, improved plant growth, photosynthesis and chlorophyll content of pea, but it decreased plant injuries (Popova et al., 2008). SA significantly increased seed germination, plant height, number of leaves, branches, root length and number of nodules as well as seed yield of ginger (Ghasemzadeh and Jaafar, 2013). Also, benzothiadiazole (BTH) has been activated induced resistance in pea plants (Dann and Deverall, 2000) and used as a defense activator in diseases management programs in many crops to produce healthy plants (Bayoumi and Hafez, 2006). Studies in Australia and Brazil revealed that BTH generally reduced diseases caused by Cladosporium oxysporum on passion fruits (Willingham et al., 2002), and Xanthomonas axonopodis pv. passiflorae (Boro et al., 2011). Besides, BTH significantly reduced plum pox virus percent and increased growth and yield of pea plants (Clemente-Moreno et al., 2010).

The objectives of this study were to evaluate the effectiveness of different safe compounds, i.e. bio-control agents, bio-stimulants (humic acid and compost tea) and induced resistance elicitors (SA and BTH) against certain soil borne diseases and improving plant growth and yield of pea plants under greenhouse and open field conditions.

\section{Materials and Methods}

\section{Source of pathogens}

The tested soil borne pathogenic fungi were Fusarium solani, Fusarium moniliforme, Fusarium oxysporum and Macrophomina phaseolina that obtained from the Plant Pathology Dept., Agric. Res. Center, Giza, Egypt. All isolates were tested against pea plants.

\section{Seed treatments}

Pea seeds (cv. Master-B) were washed several times with tap water and soaked for 30 minutes in the solution or suspension of the following tested treatments:

1- Control (untreated),

2- Biofungicide Plant guard: $1 \mathrm{ml}$ contains $30 \times 10^{6}$ spores of Trichoderma harzianum,

3- Humic acid $(8 \mathrm{ml} / \mathrm{l})$,

4- Compost tea $(25 \%)$,

5- Salicylic acid (SA) (0.5g/1),

6- BTH (benzo (1,2,3)-thiadizole-7-carbothioic acid -s- methyl ester) at $0.15 \mathrm{mM}$,

7- Fungicide treatment with Vitavax-T 75\% WP at $3 \mathrm{~g} / 1$.

Previous treatments were used as seed treatment in greenhouse (in pots) and as seed and foliage treatments under field conditions.

\section{Pot experiment}

Pathogenic tests of the isolated fungi, i.e. Fusarium solani, Fusarium moniliforme, Fusarium oxysporum and Macrophomina phaseolina were carried out under greenhouse conditions at Agric. Res. Centre, Sakha Station during 2012 season. Pea seeds were surface sterilized and sown in plastic pots $(20 \mathrm{~cm}$ diameter) containing sterilized sandy loam soil artificially infested with any of the tested fungi, which was previously grown for two weeks on sand barley medium. Each pot was sown with ten seeds. The experiment was arranged in a completely randomized design with four replicates, each replicate had five pots for each isolate and control treatment. Root rot disease incidence was estimated and calculated as percentage of pre- and post- emergence dampingoff after 15 and 30 days from sowing date, while survival pecent was after 30 days from sowing according to Abdel-Kader et al. (2012). 


\section{Field experiment}

Field experiments were cunducted during the two successive growing seasons at 2012 and 2013 in open field with the history of wilt disease at the Experimental Farm, Fac. of Agric., Kafrelshiekh Univ., Egypt. Pea treated seeds were sown on $9^{\text {th }}$ November in the first season and $15^{\text {th }}$ February in the second one on three rows in the ridge at $25 \mathrm{~cm}$ apart and $10 \mathrm{~cm}$ spacing between plants within the row, $75 \mathrm{~cm}$ width and $6 \mathrm{~m}$ length. Each plot contains three ridges with $2.25 \mathrm{~m}$ width and $6 \mathrm{~m}$ length, making $13.5 \mathrm{~m}^{2}$ plot area. Three foliar applications of all treatments were performed fortnightly starting one month after sowing. Irrigation and fertilization were applied according to good agricultural practices of growers in the region. The following measurements were recorded:

1- Plant growth parameters: Plant height $(\mathrm{cm})$, number of leaves/ plant and fresh and dry weights (g/plant).

2- Leaf chlorophyll content (SPAD): It was measured with SPAD meter (Minolta, Co., Ltd, Japan). Growth parameters and chlorophyll content were determined, 90 days after sowing.

3- Pod yield and its components: Total green mature pods and dry grain yield were harvested and recorded as ton/ha. Random samples of 50 pods were taken for physical properties, pod length and seed index (weight of 100 seeds).

4- Biochemical assays of catalase activity: It was measured in plants, $0.5 \mathrm{~g}$ fw of fully expanded young leaf material was homogenized at $0-4{ }^{\circ} \mathrm{C}$ in $3 \mathrm{ml}$ of $50 \mathrm{mM}$ TRIS buffer $(\mathrm{pH}$ 7.8 ), containing $1 \mathrm{mM}$ EDTA-Na ${ }_{2}$ and $7.5 \%$ polyvinylpyrrolidone. The homogenate was filtered through four layers of cheese cloth and centrifuged $\left(12,000 \mathrm{rpm}, 20 \mathrm{~min}, 4{ }^{\circ} \mathrm{C}\right)$ and measured spectrophotometrically at 240 nm every $30 \mathrm{sec}$ intervals for $3 \mathrm{~min}$ according to Aebi (1984).

5- Wilt \% in field expirement: Pecentages of wilting pea plants were estimated at 70 days after sowing date. Plants were examined for typical Fusarium wilting symptoms (ToledoSouza et al., 2012).

\section{Statistical analysis}

The experimental design was established as a randomized complete blocks design with four replicates. Data were analyzed using the statistical analysis of variance by SPSS and m-stat software statistical packages according to Gomez and Gomez (1984). Duncan's multiple range test was used for means comparison (Duncan, 1955).

\section{Results and Discussion}

Virulence ability of isolates on disease symptoms

All fungal isolates were able to cause root rot symptoms with different degrees in both pre and post-emergence stages of pea plants compared with the control healthy plants (Table 1). F. solani caused high significant effects on damping-off at pre and post-emergence stages with 21.4 and 28.5 $\%$, respectively. On the other hand, the highest percentage of survival pea plants was resulted by uninfected plants (control) which recorded 98.4 $\%$ compared to all infected plants with all tested pathogens.

Effect of bio safe compounds, resistance inducers and fungicide on root rot of pea plants under greenhouse conditions

Pre- and post-emergence damping-off values were significantly decreased as a result

TABLE 1. Pathogenic ability of tested fungi to induce root rot incidence on pea plants grown in pots under greenhouse conditions.

\begin{tabular}{|c|c|c|c|}
\hline \multirow[b]{2}{*}{ Tested isolates } & \multicolumn{2}{|c|}{ Root rot disease incidence (\%) } & \multirow[b]{2}{*}{ Survival plants $(\%)$} \\
\hline & Pre-emergence & Post-emergence & \\
\hline $\begin{array}{l}\text { Control } \\
\text { F. solani }\end{array}$ & $\begin{array}{l}00.7 \mathrm{~d} \\
21.4 \mathrm{a}\end{array}$ & $\begin{array}{l}00.9 \mathrm{~d} \\
28.5 \mathrm{a}\end{array}$ & $\begin{array}{l}98.4 \mathrm{a} \\
50.1 \mathrm{~d}\end{array}$ \\
\hline M. phaseolina & $14.6 \mathrm{c}$ & $22.0 \mathrm{c}$ & $63.4 \mathrm{~b}$ \\
\hline F. monilforme & $17.9 \mathrm{~b}$ & $25.3 \mathrm{~b}$ & $56.8 \mathrm{c}$ \\
\hline $\begin{array}{l}\text { F. oxysporum } \\
\text { F. test }\end{array}$ & $\begin{array}{c}17.5 \mathrm{~b} \\
* *\end{array}$ & $\begin{array}{c}24.9 \mathrm{~b} \\
*\end{array}$ & $\begin{array}{c}57.6 \mathrm{c} \\
* *\end{array}$ \\
\hline
\end{tabular}

The numbers in the same column means followed by the same letter are not significantly different according to DMRT at 0.05 level. 
of biological substances or resistance inducers treatments (Table 2). Both BTH and fungicide had significantly most effecient in reducing the root rot incidence at pre-emergence damping-off caused by Fusarium solani, Fusarium moniliform and Fusarium oxysporum without significancy between both followed by SA treatment. However, the other treatments showed lower reduction in root rot incidence than the control. Similarly, fungicide, BTH and SA followed by other treatments had more effective against the pathogens at post-emergence stage. These results are similar to those of Bayoumi \& El-Kot (2010), Boro et al. (2011) and Ghasemzadeh \& Jaafar (2013).

Effect of bio safe compounds, resistance inducers and fungicide on survival plants $\%$ under greenhouse conditions

Bilogical and resistance inducres treatments significantly enhanced survival plants $\%$ as compared to untreated control (Table 3 ). The most effective treatments against $F$. solani were the fungicide (Vitavax-T) and BTH followed by both SA and compost tea compared to control treatment which showed the lowest survival plants \% (48.80). The highest survival plants \% due to infection by F. monilforme was obtained by fungicide (96.1) followed by both BTH and compost tea compared to control (56.20). The highest survival \% due to infection by $F$. oxysporum was resulted by fungicide, BTH and compost tea followed by SA and humic acid treatments as compared to control (56.97). In regard to $M$. phaseolina, the highest survival \% was resulted by fungicide followed by BTH treatments as compared to the control (62.6). Thus, using BTH, SA, compost tea, humic acid, plant guard and the fungicide (Vitavax-T) suppressed the effect of the four pathogens under this study in most cases (Table 3). Biological control by Trichoderma spp. against pathogens might be due to mycoparasitism and competition for nutrients (Lifshitz et al., 1986), also SA is precursor molecule that mantains resistance to biotic stress in plants (Canakci, 2011). Effective control against Fusarium sp. using compost tea might be due to mycolytic effect on spores through destruction of the propagules of the pathogen (Liping et al., 2001). Defense pathway in pea plants can be activated by BTH as resistance

TABLE 2. Effect of bio safe compounds, resistance inducers and fungicide on root rot (pre and post-emergence damping-off) of pea plants in pot experiment

\begin{tabular}{|c|c|c|c|c|c|c|c|c|}
\hline \multirow[b]{2}{*}{ Treatments } & \multicolumn{4}{|c|}{ Pre-emergence } & \multicolumn{4}{|c|}{ Post-emergence } \\
\hline & F. solani & $\begin{array}{l}F \\
\text { monilforme }\end{array}$ & $\begin{array}{l}F \\
\text { oxysporum }\end{array}$ & $\begin{array}{l}M \\
\text { phaseolina }\end{array}$ & F. solani & $\begin{array}{l}F \\
\text { monilforme }\end{array}$ & $\begin{array}{l}F \\
\text { oxysporum }\end{array}$ & $\begin{array}{l}M \\
\text { phaseolina }\end{array}$ \\
\hline 1-Control & $22.20 \mathrm{a}$ & $18.20 \mathrm{a}$ & $18.08 \mathrm{a}$ & $15.20 \mathrm{a}$ & $29.00 \mathrm{a}$ & $25.60 \mathrm{a}$ & $24.95 \mathrm{a}$ & $22.20 \mathrm{a}$ \\
\hline 3-Humic acid ( $8 \mathrm{~m} / / 1)$ & $11.00 \mathrm{c}$ & $11.80 \mathrm{~b}$ & $06.40 \mathrm{c}$ & $09.25 \mathrm{~b}$ & $03.11 \mathrm{~d}$ & $10.30 \mathrm{~b}$ & $03.01 \mathrm{c}$ & $05.01 \mathrm{~d}$ \\
\hline 4- Compost tea $(25 \%)$ & $12.20 \mathrm{~b}$ & $12.50 \mathrm{~b}$ & $02.11 \mathrm{~d}$ & $09.25 \mathrm{~b}$ & $03.20 \mathrm{~d}$ & $06.25 \mathrm{c}$ & $03.01 \mathrm{c}$ & $14.20 \mathrm{~b}$ \\
\hline 7-Fungicide (3g/l) & $00.25 \mathrm{~d}$ & $01.30 \mathrm{~d}$ & $01.05 \mathrm{~d}$ & $01.25 \mathrm{~d}$ & $03.01 \mathrm{~d}$ & $02.60 \mathrm{~d}$ & $03.01 \mathrm{c}$ & $05.20 \mathrm{~d}$ \\
\hline
\end{tabular}

The numbers in the same column means followed by the same letter are not significantly different according to DMRT at 0.05 level.

TABLE 3. Effect of bio safe compounds, resistance inducers and fungicide on survival plants \% caused by fungal isolates under greenhouse conditions

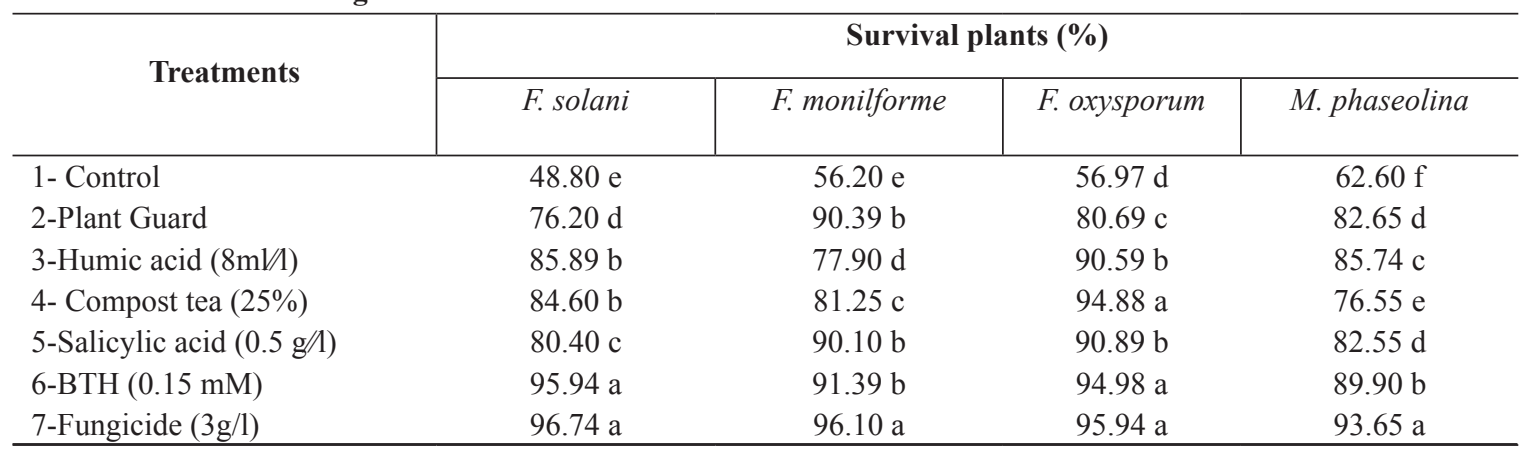

The numbers in the same column means followed by the same letter are not significantly different according to DMRT at 0.05 level 
inducer to root rot diseases by increasing SAR pathways plants (Thakur and Sohal, 2013).

Effect of bio safe compounds, resistance inducers and fungicide on vegetative growth characters of pea plants under field conditions

Plant growth parameters as affected by different safety compounds are presented in Tables 4 and 5. All vegetative growth parameters (plant height, number of leaves/plant, fresh and dry weights/plant) were significantly enhanced as a sequence of the most treatments as compared to untreated plants. Humic acid, compost tea, salicylic acid and BTH applications generally, produced the best results of all growth parameters without significant differences from each other in most cases in both seasons. The lowest growth values were resulted from untreated plants (control) followed by plants treated with plant guard (T. harzianum).
The favorable effects of compost tea and humic acid on plant growth might be due to improve the nutrients efficiency by their role in the cation exchange capacity (Ingham, 2003) and their suppressive effect on plant pathogens as observed in this study (Tables, $2 \& 3$ and Fig. 3 ) through reducing the disease incidence and severity (Francesco et al., 2004). In addition, the vigorous growth of pea plants caused by compost tea and humic acid applications may be attributed to their physiochemical properties and sufficient nutrients for growth and bio-agents (Haggag and Saber, 2007) which improved pea growth. Also, high content of microorganisms of compost tea increased biological activity which improved plant growth (Siddiqui et al., 2008). Therefore, humic substance stimulates plant proton pumps and elevates root growth by providing an auxinlike bioactivity and finally promoting plant growth (Zandonadi et al., 2016).

TABLE 4. Effect of bio safe compounds, resistance inducers and fungicide on some vegetative growth parameters of pea plants in 2012 and 2103 seasons under field conditions

\begin{tabular}{|c|c|c|c|c|}
\hline \multirow[t]{2}{*}{ Treatments } & $\begin{array}{c}\text { Plant height } \\
\text { (cm) }\end{array}$ & $\begin{array}{c}\text { No. of leaves } / \\
\text { plant }\end{array}$ & $\begin{array}{l}\text { Plant height } \\
\text { (cm) }\end{array}$ & $\begin{array}{l}\text { No. of leaves } \\
\text { plant }\end{array}$ \\
\hline & \multicolumn{2}{|c|}{2012 season } & \multicolumn{2}{|c|}{2013 season } \\
\hline 1-Control & $68.9 \mathrm{e}$ & $12.9 \mathrm{c}$ & $80.1 \mathrm{c}$ & $14.8 \mathrm{~b}$ \\
\hline 2-Plant Guard & $73.3 \mathrm{~d}$ & $12.2 \mathrm{c}$ & $80.7 \mathrm{c}$ & $12.8 \mathrm{c}$ \\
\hline 3-Humic acid $(8 \mathrm{~m} / / 1)$ & $86.1 \mathrm{~b}$ & $18.2 \mathrm{a}$ & $96.8 \mathrm{a}$ & $19.3 \mathrm{a}$ \\
\hline 4- Compost tea $(25 \%)$ & $84.5 \mathrm{~b}$ & $17.6 \mathrm{a}$ & $91.6 \mathrm{~b}$ & $18.4 \mathrm{a}$ \\
\hline 5-Salicylic acid $(0.5 \mathrm{~g} / 1)$ & $86.4 \mathrm{~b}$ & $18.1 \mathrm{a}$ & $94.1 \mathrm{a}$ & $18.7 \mathrm{a}$ \\
\hline 6-BTH (0.15 mM) & $90.2 \mathrm{a}$ & $18.4 \mathrm{a}$ & $96.7 \mathrm{a}$ & $19.3 \mathrm{a}$ \\
\hline 7-Fungicide (3g/1) & $77.6 \mathrm{c}$ & $14.1 \mathrm{~b}$ & $82.8 \mathrm{c}$ & $15.3 \mathrm{~b}$ \\
\hline
\end{tabular}

The numbers in the same column means followed by the same letter are not significantly different according to DMRT at 0.05 level.

TABLE 5. Effect of bio safe compounds, resistance inducers and fungicide on fresh and dry weights of pea plants grown under field conditions during 2012 and 2103 seasons

\begin{tabular}{lcccc}
\hline \multicolumn{1}{c}{ Treatments } & $\begin{array}{c}\text { Plant fresh weight } \\
(\mathbf{g})\end{array}$ & $\begin{array}{c}\text { Plant dry } \\
\text { weight }(\mathbf{g})\end{array}$ & $\begin{array}{c}\text { Plant fresh } \\
\text { weight }(\mathbf{g})\end{array}$ & Plant dry weight (g) \\
\cline { 2 - 5 } & \multicolumn{2}{c}{ 2012 season } \\
\hline 1-Control & $110.8 \mathrm{e}$ & $21.2 \mathrm{~d}$ & $121.8 \mathrm{e}$ & 2013 season \\
2-Plant Guard & $116.4 \mathrm{~d}$ & $23.5 \mathrm{c}$ & $124.2 \mathrm{c}$ & $23.8 \mathrm{c}$ \\
3-Humic acid (8mV//) & $140.7 \mathrm{c}$ & $26.8 \mathrm{~b}$ & $166.3 \mathrm{a}$ & $31.5 \mathrm{a}$ \\
4- Compost tea (25\%) & $141.3 \mathrm{c}$ & $27.1 \mathrm{~b}$ & $153.6 \mathrm{~b}$ & $28.8 \mathrm{~b}$ \\
5-Salicylic acid (0.5 g//) & $156.4 \mathrm{a}$ & $31.3 \mathrm{a}$ & $165.4 \mathrm{a}$ & $31.4 \mathrm{a}$ \\
6-BTH (0.15 $\mathrm{mM})$ & $147.9 \mathrm{~b}$ & $30.5 \mathrm{a}$ & $167.1 \mathrm{a}$ & $32.3 \mathrm{a}$ \\
7-Fungicide (3g/l) & $115.6 \mathrm{~d}$ & $21.7 \mathrm{~d}$ & $123.7 \mathrm{c}$ & $23.1 \mathrm{c}$ \\
\hline
\end{tabular}

The numbers in the same column means followed by the same letter are not significantly different according to DMRT at 0.05 level. 
The best results with SA applications on growth parameters of pea plants suggest that SA increases photosynthetic rate due to increased $\mathrm{CO}_{2}$ uptake and enzyme-related activities. These results are in agreement with those obtained by Nagasubramaniam et al. (2007) who cleared that SA increased plant height, leaf area, crop growth rate and total dry matter in baby corn.

Effect of bio safe compounds, resistance inducers and fungicide on chlorophyll content of pea plants under field conditions

The application of safe compounds and resistance inducers caused a significant increase in chlorophyll content compared to untreated plants in both seasons (Fig. 1). Plants treated with SA, BTH, compost tea and humic acid had the highest chlorophyll content without significant differences in between, while untreated plants gave the lowest values in most cases (Fig. 1). Using plant guard (T. harzianum) and Vitavax (fungicide) showed the intermediate values in both seasons. These results are in agreement with those obtained by other researchers which show that SA and humic acid significantly increases pigments content (Ghasemzadeh \& Jaafar, 2013 and Yasir et al., 2016). The superiority effect of BTH and SA on the chlorophyll content may be due to their suppressive role on disease severity $\%$ (Tables 2 and 3 as well as Fig. 3), which stimulated plant growth as well as enhanced photosynthesis process by enhancing chlorophyll content in pea leaves. Also, the excellence effect of compost tea and humic acid on the chlorophyll content may be due to their high nutrient contents, which stimulate the chlorophyll synthesis. This result may be attributed to high contents of humic acids in both humic and compost tea which consider the main component for hormone-like activators of humic materials through their involvement in cell respiration, photosynthesis, protein synthesis and various enzymatic reactions (Atiyeh et al., 2002).

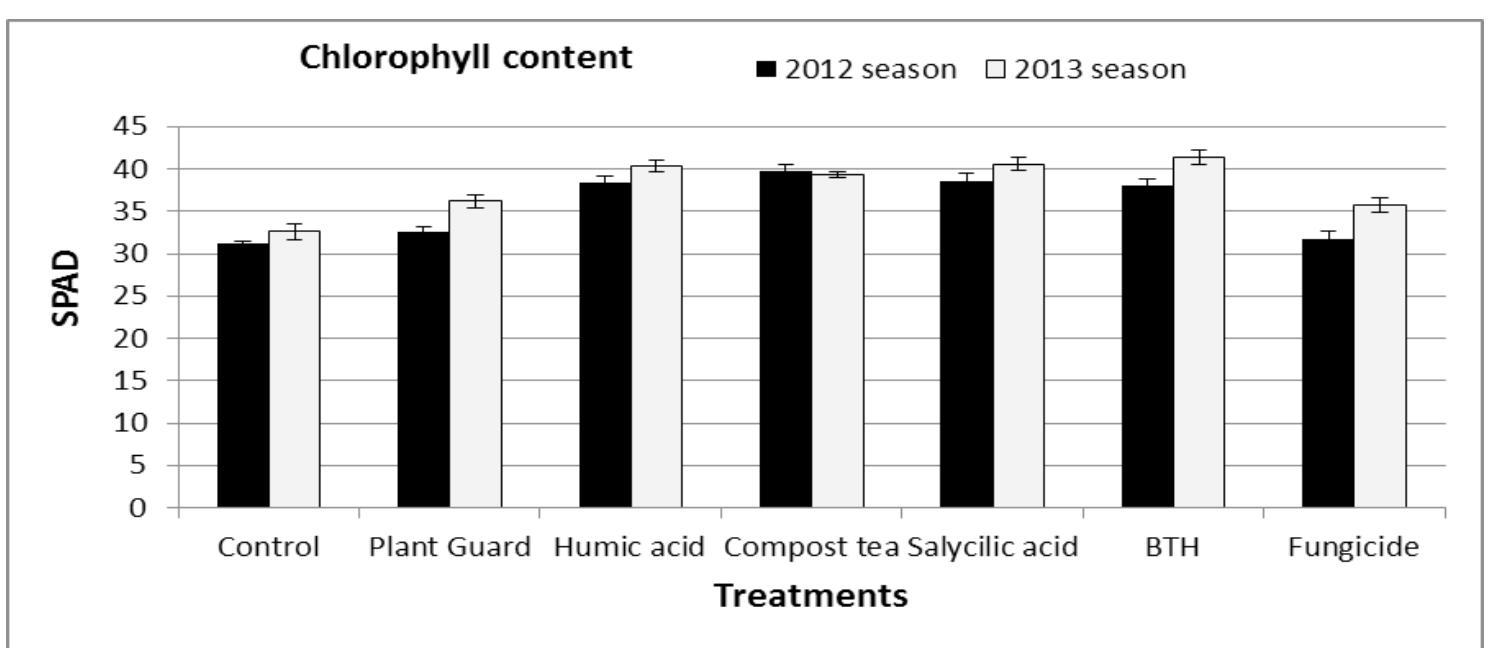

Fig. 1. Effect of different treatments on chlorophyll content of pea plants in 2012 and 2013 seasons

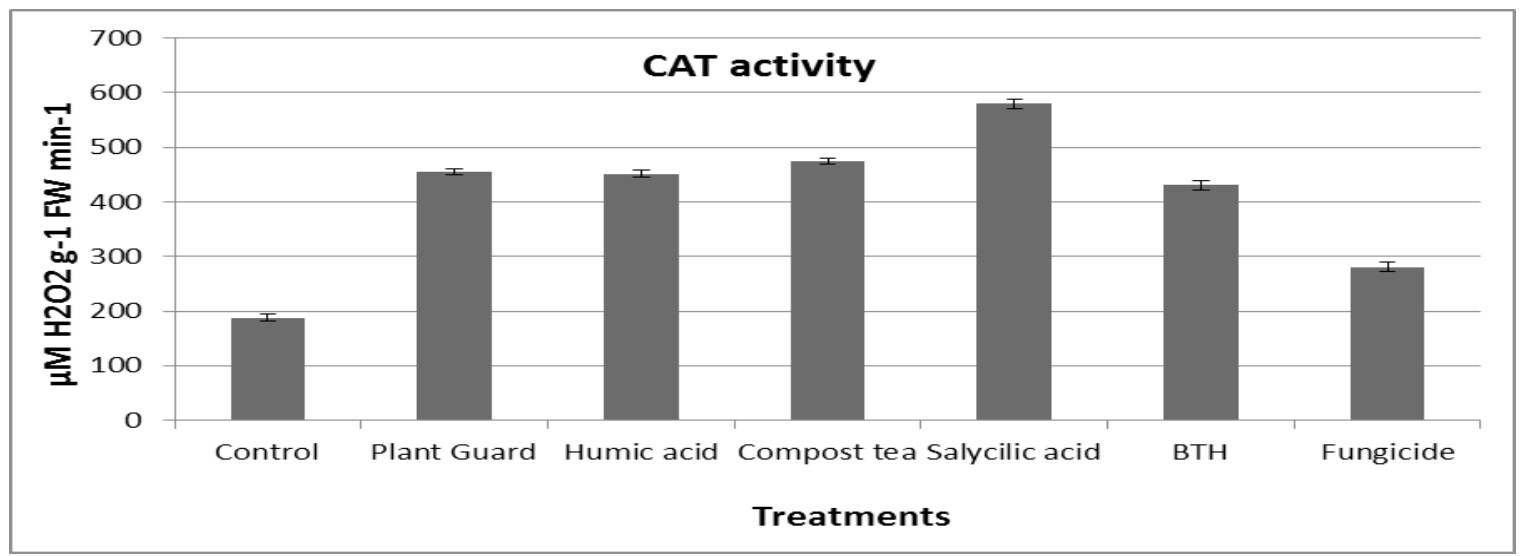

Fig. 2. Effect of bio safe compounds, resistance inducers and fungicide on catalase activity of pea plants infected with Fusarium oxysporum f.sp. pisi

J. Sus. Agric. Sci. 43, No.3 (2017) 


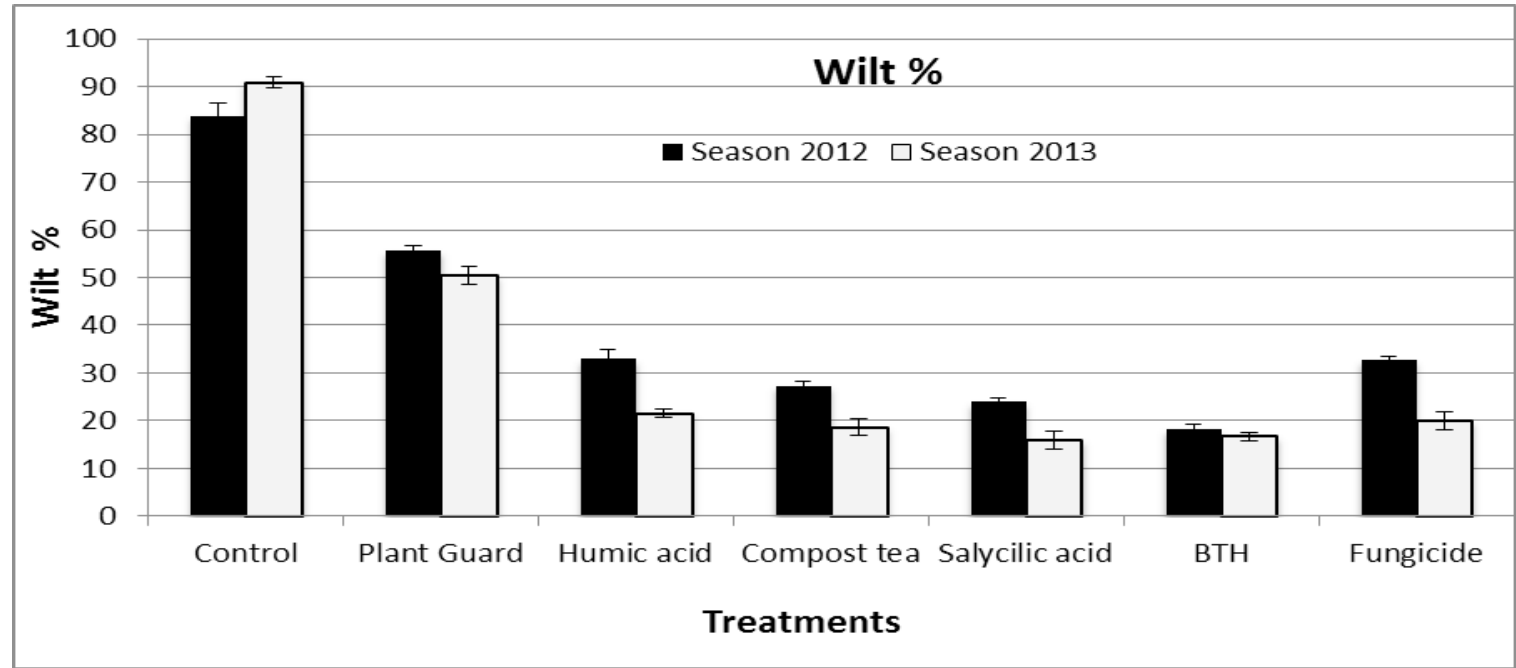

Fig. 3. Effect of bio safe compounds, resistance inducers and fungicide on wilt $\% 70$ days after sowing of pea plants infected with Fusarium oxysporum f.sp. pisi during 2012 and 2013 seasons under field conditions

Effect of bio safe compounds, resistance inducers and fungicide on pod and seed yield and its components of pea plants grown under field conditions

Both green pod and dry seed yields of pea plants (ton/ha) were significantly increased as a result of application the safety compounds and resistance inducers. The results were somewhat different between the two seasons. In the first season, the largest green pod yield was produced by SA and BTH followed by compost tea, humic acid, fungicide treatment and plant guard (T. harzianum) compared to untreated control plants (Table 6). The highest green pod yield in the first season was 12.99 ton/ha and 12.01 ton/ ha obtained by compost tea and BTH treatments, respectively, without significant differences between both treatments. However, in the second season the highest values were recorded by using SA (13.64 ton/ha) and compost tea (13.07 ton/ha) without significant differences in between (Table 6). Likewise, dry seed yields were the highest with compost tea and BTH treatments during the first season (2.64 and 2.58 ton/ha, respectively), which such yields were 2.81 and 2.79 ton/ha with SA and compost tea treatments respectively, in the second season. The obtained results concur with similar results provided by Espýn et al. (2011).

TABLE 6. Effect of bio safe compounds, resistance inducers and fungicide on green pod and total dry seed yields of pea plants in 2012 and 2013 seasons under field conditions

\begin{tabular}{|c|c|c|c|c|}
\hline \multirow[t]{2}{*}{ Treatments } & $\begin{array}{c}\text { Green pod yield } \\
\text { (ton/ha) }\end{array}$ & $\begin{array}{c}\text { Dry seed yield } \\
\text { (ton/ha) }\end{array}$ & $\begin{array}{c}\text { Green pod yield } \\
\text { (ton/ha) }\end{array}$ & $\begin{array}{c}\text { Dry seed yield } \\
\text { (ton/ha) }\end{array}$ \\
\hline & \multicolumn{2}{|c|}{2012 season } & \multicolumn{2}{|c|}{2013 season } \\
\hline 1-Control & $7.77 \mathrm{~d}$ & $1.65 \mathrm{~d}$ & $8.69 \mathrm{e}$ & $1.78 \mathrm{~d}$ \\
\hline 2-Plant Guard & $10.88 \mathrm{~b}$ & $2.20 \mathrm{~b}$ & $9.96 \mathrm{c}$ & $2.15 \mathrm{c}$ \\
\hline 3-Humic acid $(8 \mathrm{~m} / / 1)$ & $10.65 \mathrm{~b}$ & $2.15 \mathrm{~b}$ & $12.15 \mathrm{~b}$ & $2.52 \mathrm{~b}$ \\
\hline 4- Compost tea ( $25 \%)$ & $12.99 \mathrm{a}$ & $2.64 \mathrm{a}$ & $13.07 \mathrm{a}$ & $2.79 \mathrm{a}$ \\
\hline 5-Salicylic acid $(0.5 \mathrm{~g} / \mathrm{\Lambda})$ & $10.71 \mathrm{~b}$ & $2.05 \mathrm{~b}$ & $13.64 \mathrm{a}$ & $2.81 \mathrm{a}$ \\
\hline 6-BTH (0.15 mM) & $12.01 \mathrm{a}$ & $2.58 \mathrm{a}$ & $12.01 \mathrm{~b}$ & $2.59 \mathrm{~b}$ \\
\hline 7-Fungicide (3g/l) & $9.89 \mathrm{c}$ & $1.92 \mathrm{c}$ & $9.95 \mathrm{~d}$ & $2.11 \mathrm{c}$ \\
\hline
\end{tabular}

The numbers in the same column means followed by the same letter are not significantly different according to DMRT at 0.05 level. 
The stimulative effect of safe compounds on increasing pea yields may be due to their effects on plant growth (Tables 4 and 5) and chlorophyll content (Fig.1) which reflected positively on the yield. Furthermore, all safe compounds significantly reduced the incidence of dampingoff and root rot severity of pea plants (Tables 2 and 3 as well as Fig. 3) and consequently led to improvement pea growth and increase the green and dry yields. Increasing pea yields as a result of using humic acids and compost tea may be attributed to enhancing the growth which mainly due to their high contents of organic and mineral substances with hormone-like activities through their involvement in photosynthesis, proteins synthesis and various enzymatic reactions (Atiyeh et al., 2002 and Gad El-Hak et al., 2012). Similar increments in total yields were obtained by Mohajerani et al. (2016) on beans, Shehata et al. (2016) on lettuce and Yasir et al. (2016) on cucumber. The data in Table 7 show that both of pod length and weight of 100 seeds of peas were non-significantly influenced by treatments in both seasons.
Effect of bio safe compounds, resistance inducers and fungicide on antioxidant enzyme (catalase) of pea plants under field conditions

It is clear from data shown in Fig. 2 that, seed and spraying treatments of pea plants with all safe compounds and resistance inducers significantly increased catalase enzyme activity as compared to untreated plants. The results showed that SA followed by compost tea had significantly more effective than the other treatments as compared to untreated plants which showed the lowest activity in most cases. However, applying humic acid, plant guard, BTH and fungicide resulted in the intermediate values in most cases. High catalase activity in pea leaves was reflected on the high resistance of plant against diseases and this increment may be higher around the infection sites (Raghavendra et al., 2007) which may be played a role in the inhibition of fungal disease severity (Tables 2 and 3), thereby enhanced the vegetative growth, chlorophyll content and consequently increased both of green and dry pea yields (Table $6)$. These results are in agreement with those of Bayoumi \& El-Kot (2010) and Sharma (2012).

TABLE 7. Effect of bio safe compounds, resistance inducers and fungicide on pod length and seed index of pea plants in both seasons

\begin{tabular}{|c|c|c|c|c|}
\hline \multirow{2}{*}{ Treatments } & Pod length (cm) & Seed index (g) & Pod length (cm) & Seed index (g) \\
\hline & \multicolumn{2}{|c|}{2012 season } & \multicolumn{2}{|c|}{2013 season } \\
\hline 1-Control & $9.6 \mathrm{a}$ & $35.4 \mathrm{a}$ & $9.8 \mathrm{a}$ & $34.9 \mathrm{a}$ \\
\hline 2-Plant Guard & $9.8 \mathrm{a}$ & $35.8 \mathrm{a}$ & $10.1 \mathrm{a}$ & $34.9 \mathrm{a}$ \\
\hline 3-Humic acid $(8 \mathrm{~m} / / 1)$ & $10.1 \mathrm{a}$ & $36.4 \mathrm{a}$ & $9.9 \mathrm{a}$ & $36.6 \mathrm{a}$ \\
\hline 4- Compost tea $(25 \%)$ & $10.2 \mathrm{a}$ & $36.3 \mathrm{a}$ & $9.9 \mathrm{a}$ & $35.9 \mathrm{a}$ \\
\hline 5-Salicylic acid $(0.5 \mathrm{~g} / 1)$ & $10.3 \mathrm{a}$ & $36.0 \mathrm{a}$ & $10.3 \mathrm{a}$ & $36.8 \mathrm{a}$ \\
\hline 6-BTH $(0.15 \mathrm{mM})$ & $10.4 \mathrm{a}$ & $35.8 \mathrm{a}$ & $10.2 \mathrm{a}$ & $36.7 \mathrm{a}$ \\
\hline 7-Fungicide (3g/1) & $9.4 \mathrm{a}$ & $35.6 \mathrm{a}$ & $9.6 \mathrm{a}$ & $35.6 \mathbf{a}$ \\
\hline
\end{tabular}

These results supported the idea that upregulation of antioxidants as a results of resistance inducers or early accumulation of reactive oxygen species (ROS) could protect plants from stresses caused by biotic or abiotic stresses (Hagag et al., 2016).

Effect of bio safe compounds, resistance inducers and fungicide on wilt \% of F. oxysporum $f$. sp. pisi in pea plants under field conditions

As a result of treatment with BTH, SA, humic acid, compost tea, fungicide and plant guard (T. harzianum) treatments, Fusarium wilt disease symptoms were significantly suppressed (Fig. 3). Severe Fusarium wilting was observed with untreated plants (control) which showed the highest disease severity \% (83.9) and (90.8) in both seasons, respectively. The reduction in disease severity $\%$ due to using most of safety compounds and resistance inducers may be due to their role in induced resistance in pea plants treated with most of treatments, this induced resistance associated with enzymes activity in pea leaves (Fig. 2). BTH and SA have been the best disease reduction in pea and this might be related to induction of phytoalexins in plants as reported 
by Kuc (2006). High enzyme activity reflects the high resistance of plant against diseases and this increase may play a role in the inhibition of fungal establishment (Tables 2 and 3). These results are supported with those conducted by Bayoumi \& El-Kot (2010) and Barilli et al. (2015).

\section{Acknowledgment}

The authors thank the staff members of EPCRS Excellence Centre as well as Plant Pathology and Biotechnology Lab., Dept. Agric. Botany, Fac. Agric., Kafrelsheikh University, Kafr-Elsheikh, Egypt for conducting the biochemical assays as well as the staff of Microbiology Dept., Agric. Res. Cent., Sahka Station for providing humic acid and compost tea components.

\section{References}

Abdel-Kader, M.M., El-Mougy, Nehal S. and Lashin M.D.A. (2012) Different approaches of bio- control agents for controlling root rot incidence of some vegetables under greenhouse conditions. Scientific \& Academic Publishing, 2(1),115:127.

Aebi, H. (1984) Catalase in vitro. Method in Enzymology, Academic Press, New York, 105,121126.

Atiyeh, R.M., Lee, S., Edward, C.A., Arancon, N.Q. and Metzger, J.D. (2002) The influence of humic acids derived from earthworm-processed organic wastes on plant growth. Bioresource Technol., 84,7-14.

Barilli, E., Rubiales, D., Amalfitano, C., Evidente, A. and Prats, E. (2015) BTH and BABA induce resistance in pea against rust (Uromyces pisi) involving differential phytoalexin accumulation. Planta, 242,1095-1106.

Bayoumi, Y.A. and El-Kot, G.A.N. (2010) Potential impacts of different aqueous compost extracts on growth, yield, enzyme activities and controlling powdery mildew of cucumber plants grown under plastic houses. Minufiya J. Agric. Res., 35 (2),649-661.

Bayoumi, Y.A. and Hafez, Y.M. (2006) Effect of organic fertilizers combined with benzo $(1,2,3)$ thiadiazole-7-carbothioic acid S-methyl ester (BTH) on the cucumber powdery mildew and the yield production. Acta Biologica Szegediensis, 50 (3-4),131-136.
Boro, M.C., Beriam, L.and Guzzo, S.D. (2011) Induced resistance against Xanthomonas axonopodis pv. passiflorae in passion fruit plants. Trop. Plant Pathol., 36,74-80.

Callan, N.W., Mathre, D.E., Miller, I.B. and Vavrina, C.S. (1997) Biological seed treatments, factors affecting their efficacy. Hort. Science, 32,179-183.

Canakci, S. (2011) Effect of salicylic acid on growth, biochemical constituents in pepper (Capsicum annuum L.) seedlings. Pak. J. Bio. Sci., 14 (4), 300 304.

Clemente-Moreno, M.J., Díaz-Vivancos, Barba-Espín, P.G. and Hernández, J.A. (2010) Benzothiadiazole and 1-2-oxothiazolidine-4-carboxylic acid reduce the severity of Sharka symptoms in pea leaves: effect on antioxidative metabolism at the subcellular level. Plant Biol., 12 (1), 88-97.

Dann, E.K. and Deverall, B.J. (2000) Activation of systemic disease resistance in pea by an avirulent bacterium or a benzothiadiazole, but not by a fungal leaf spot pathogen. Plant Pathol., 49, 324-332.

Duncan, D. B. (1955) Multiple range and multiple F-test. Biometrics, 11, 1-42.

Espýn, Barba G., Moreno, C., Alvarez, S., GarcýaLegaz, M.F., Hernandez, J.A. and Dýaz-Vivancos, P. (2011) Salicylic acid negatively affects the response to salt stress in pea plants. Plant Biology, 13, 909-917.

FAO (2014) FAO Stat data (www. fao.org/ faostat/ en/\# data/ QC).

Francesco, V., Ambrosio, G.D., Abadi, K., Scala, F., Marra, R., Turr, D., Woo, S.L., and Lorito, M. (2004) Application of Trichoderma harzianum (Y22) and T. viride (p1) as plant growth promoters, and their compatibility with copper oxychloride. $J$. Agric. \& Life Sci., 30 (4), 425.

Gad El-Hak, S.H., Ahmed, A.M. and Moustafa, Y.M.M. (2012) Effect of foliar application with two antioxidants and humic acid on growth, yield and yield components of peas (Pisum sativum L.). J. Hort. Sci. \& Ornam. Plants, 4 (3),318-328.

Ghanbarzadeh, B., Safaie, N., Goltapeh, E.M., Danesh, Y.R. and Khelghatibana, F. (2016) Biological control of Fusarium basal rot of onion using 
Trichoderma harzianum and Glomus mosseae. J. Crop Protection, 5 (3),359-368.

Ghasemzadeh, A. and Jaafar, H.Z.E. (2013) Interactive effect of salicylic acid on some physiological features and antioxidant enzymes activity in ginger (Zingiber officinale Roscoe). Molecules, 18, 59655979.

Gomez, K.A. and Gomez, A.A. (1984) Statistical Procedures for Agriculture Research. Second ed. Willey-Inter-Science Publication, 690 pp.

Hafez, Y.M., Soliman, N.K., Saber, M.M., Imbabi, I.A. and Abd-Elaziz, A.S. (2014) Induced resistance against Puccinia triticina the causal agent of wheat leaf rust by chemical inducers. Egypt. J. of Biol. Pest Cont. 24 (1),173-181.

Hagag, Eman S., Taha, Naglaa A. and Hafez, Y.M. (2016) Control of root-knot nematode (Meloidogyne incognita) on eggplant plants using biotic and abiotic inducers of resistance. Egypt. J. Biol. Pest Cont. 26(2), 269-275.

Haggag, Wafaa M. and Saber, M.S. (2007) Suppression of early blight on tomato and purple blight on onion by foliar sprays of aerated and non-aerated compost teas. J. Food, Agric. \& Environ., 5,302-309

Kim, M.J., Shim, C.K., Kim, Y.K., Hong, S.J., Park, J.H., Han, E.J., Kim, J.H. and Kim, S.C. (2015) Effect of aerated compost tea on the growth promotion of lettuce, soybean, and sweet corn in organic cultivation. Plant Pathol J. 31(3), 259-268.

Kuc, J. (2006) What's old and What's new in concepts of induced systemic resistance in plants, and its application. In: Multigenic and Induced Resistance in Plants, S. Tuzun and E. Bent (Ed.) Springer, US :9-20.

Ingham, E.R. (2003) The Compost Tea Brewing Manual. 4th ed, Soil Food Web, Inc., Corvallis, Oregon, 88pp.

Lifshitz, R., Windham, M.T. and Baker R. (1986) Mechanism of biological control of preemergence damping-off of pea by seed treatment with Trichoderma spp. Phytopathol. 76(7),720-725.

Liping, M.A., Xiongwu, Q., Fen, G.A.O. and Bianqing, H.A.O. (2001) Control of sweet pepper Fusarium wilt with compost extracts and its mechanisms. Chinese J. Appl. Environ. Biol., 7,84-87.
Martin, C.C.G.St. and Brathwaite, R.A.I. (2012) Compost and compost tea: Principles and prospects as substrates and soil-borne disease management strategies in soil-less vegetable production. Biolo. Agri. \& Hort. 1-33.

Mohajerani, S., Fazel, M.A., Madani, H., Lak, S. and Modhej, A.l. (2016) Effect of the foliar application of humic acid on red bean cultivars (Phaseolus vulgaris L.). J. Experi. Biol. and Agric. Sci. 4 (5), 519-524.

Nagasubramaniam, A., Pathmanabhan, G. and Mallika, V. (2007) Studies on improving production potential of baby corn with foliar spray of plant growth regulators. Ann. Rev. Plant Physiol. Plant Mol. Biol. 21,154-157.

Popova, L., Maslenkova, L., Yordanova, R., Krantev, A., Szalai, G. and Janda, T. (2008) Salicylic acid protects photosynthesis against cadmium toxicity in pea plants. Gen. Appl. Plant Physiol. 34 (34), 133-148.

Raghavendra, M.P., Kumar, P.R. and Prakash, V. (2007) Mechanism of inhibtion of rice bran lipase by polyphenols: A case study with chlorogenic acid and caffeic acid. J. Food Science, 72(8),412-419.

Sharma, R.K. (2012) Effect of salicylic acid and gibberellic acid on seed germination and growth of pea. Inter. J. of Plant Science, 7(2),322-324.

Shehata, S.M., Schmidhalter, U., Valšíková, M. and Junge, H. (2016) Effect of bio-stimulants on yield and quality of head lettuce grown under two sources of nitrogen. Gesunde Pflanzen, 68 (1), 33-39.

Siddiqui, Yasmeen, Meon, S., Ismail, R., Rahmani, M. and Ali, A. (2008) Bio-efficiency of compost extracts on the wet rot incidence, morphological and physiological growth of okra (Abelmoschus esculentus L. Moench). Scientia Horticulturae, 117,9-14.

Thakur, M. and Sohal, B.S. (2013) Role of elicitors in inducing resistance in plants against pathogen infection: A review. Biochemistry ID 762412, (http://dx.doi.org/10.1155/2013/762412).

Toledo-Souza, Eliane D., Silveira, P.M., Café-Filho, A.C. and Junior, M.L. (2012) Fusarium wilt incidence and common bean yield according to the preceding crop and the soil tillage system. Pesq. Agropec. Bras., Brasilia, 47 (8), 1031-1037. 
Willingham, S.L., Pegg, K.G., Langdom, P.W.B., Cooke, A.W. Beasley, D. and Mclennan, R. (2002) Combinations of strobilurin fungicides and acibenzolar (Bion) to reduce scab on passion fruit cause by Cladosporium oxysporum. Aust. Plant Pathol. 31, 333-336.

Yasir, N. F., Seheib, M.W. and Odhafa, A.H. (2016) Effect of adding different organic fertilizers in the absorption of some of nutrient elements from soil in properties of plant growth and yield of cucumber plant. Global J. Agric. Res. 4 (6),13-19.

Zandonadi, D.B., Santos, M.P., Caixeta, L.S., Marinho, E.B., Peres, L.E.P. and Façanha, A.R. (2016) Plant proton pumps as markers of biostimulant action. Sci. agric. Piracicaba, Braz., 73(1), http://dx.doi. org/10.1590/0103-9016-2015-0076.

(Received: 29/8/2017;

accepted: 31/10/2017) 